症例

\title{
乳癌骨転移における高 $\mathrm{Ca}$ 血症クリーゼの 1 治験例
}

\author{
清水市立清水総合病院外科， \\ 安藤浩住吉健一安藤二郎小坂昭夫
}

悪性腫瘍に伴う高 Ca 血症の中で, クリーぜをきたす症例は稀である.今回, 骨転移を 伴ら進行乳癌に高 $\mathrm{Ca}$ 血症クリーゼを合併した症例を経験したので報告する。症例は, 32 歳女性で, 骨, 肝, 肺, 胃などに転移を認める進行乳癌であった。乳癌術後 3 力月に呕 気, 叹吐, 傾眠傾向などの症状を訴之精查の結果, 高 Ca 血症クリーゼと診断された。 大 量輸液，ハイドロコルチンン，カルシトニンなどの投与により著明に効果がみられ，約 1 週問後には血清 $\mathrm{Ca}$ 值は正常に戻り，症状す軽快した。

また，当院における stage IV 及び再発乳癌に合併した高 Ca 血症について検討した結 果, 骨之他部位, 骨転移, 他部位転移の順で高 Ca 血症が起こりやすく, 骨転移が誘因に なっていることが示唆された，覀性腫痬による高 Ca 血症の症状は悪性腫瘍の末期症状 と類似しているため見落とされやすく，同時に乳癌の内分泌療法中, 副作用としての高 Ca 血症にも留意する必要がある。

索引用語：乳癌，骨転移，高 Ca 血症クリーセ

\section{緒 筁}

一般的に悪性腫䨩に伴 5高 Ca 血症クリーゼは, 甲 状腺及び副肾クリーゼに比して臨床症状が重篤でな くまた癌の末期症状に類似するため見落とされやす いといわれている.

今回骨転移を伴う乳癌に高 Ca 血症クリーゼを合併 した症例を程験したので，文献的考察と同時に臨床に おける血清 $\mathrm{Ca}$ 値測定の重要性についても併せて報告 する。

患者：32歳，女性。

主訴：呕気, 呕吐, 傾眠傾向.

家族歴：特記すべきことなし。

既往歴：特記すべきことなし。

現病歴：昭和61年 2 月他院にて右乳癌と診断される も放置していた。昭和61年12月腰痛出現. 昭和62年 1 月吐血にて当院受診, 胃内視鏡検查にて噴門直下前壁 に Borr. 2型様の畽瘍を認めた，右乳癌は $\mathrm{E}$ 領域を中 心に $T_{4} N_{2} M_{1}$ の Stage IV で, 病理検査結果では, solid tubular ca.で，ホルモン学的検查では ER $(+), P g R$ （十）であった（図 1). 胸部レ線，胸部 CT 検査にて 両肺にびまん性の転移を認めた, 腹部超音波娭査, 腹

1989年 2 月 22 日受付 1989 年 7 月 5 日採用

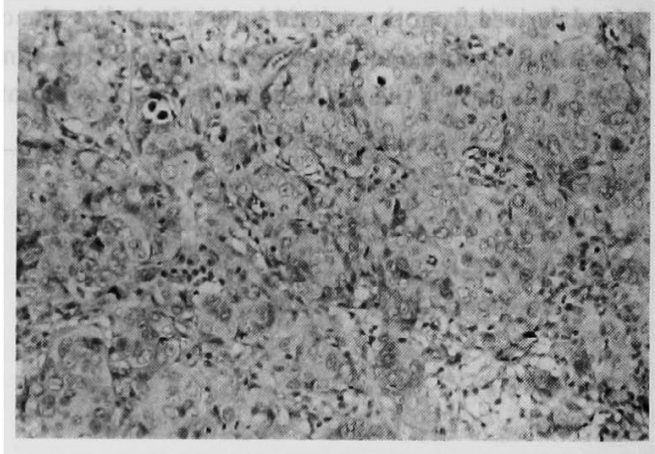

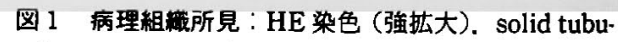
lar carcinoma 癌細胞が索状構造をとり密に增殖し ている.

部 CT 㮆查, 腹部血管造影では明らかな訮転移所見は なく、 ${ }^{99 m} \mathrm{Tc}$ 骨シンチグラフィーでは多発性の骨転移 像が同時に認められた(図 2 ). CAF+タモキシフェン の内分泌・化学療法を施行し同年 2 月胃全摘術 (Roux-Y 吻合)，丙側卵巣副腎摘出術施行した. 術中所 見は $\mathrm{S}_{0} \mathrm{P}_{0} \mathrm{H}_{3} \mathrm{~N}_{1}$ でびまん性の肝転移が認められた，病 理組織検查所見の結果, 胃癌は乳癌からの転移である ことが強く疑われた．同年 3 月，乳癌に対しては非定 型乳房切断術 $(\mathrm{Br}+\mathrm{Ax})$ を施行した。術後経過は順調 にて退院，以後タモキシフェン，サイクロフォスフフ 


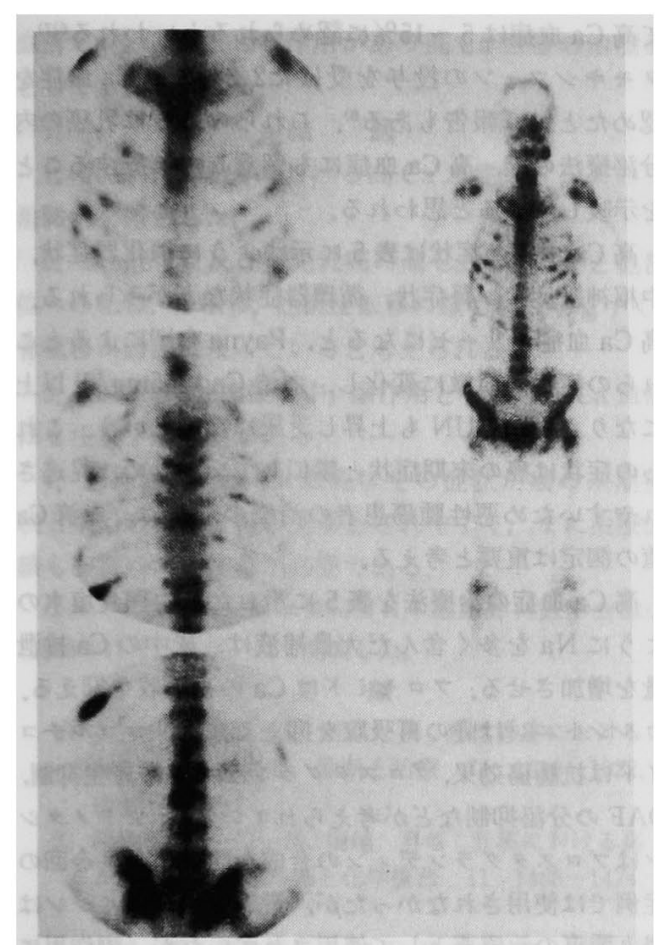

图 $2{ }^{99 m} \mathrm{Tc}$ 骨シンチクラフィー：春椎, 胸骨, 助骨な どへの多発集積像が認められる。

ミド，ハイドロコルチソンなどを投与し外来通院して いた. 同年 6 月呕気，呕吐，傾眠傾向が出現し検査に て高 Ca 血症が疑われたため入院した。

入院時現症：血王150/90mmHg, 脈拍 $90 /$ 分，体格中 等度，栄美不良．眼䀫結膜に負血は認めず，眼球結膜 に黄庭る認めなかった。同時に，傾眠傾向が強く認め られた。

入院時理学的所見：胸部㯖診，打診上異常なく，腹 部は平坦で触診上王痛なく，聴診です腸雑音の亢進な ども認められなかった。

入院時検查所見：血夜生化学検査にて肝細胞醭素, 胆道系酵素の中等度以上と血清 $\mathrm{Ca}$ の高値が認めら れ, CEA, IAP の腫煬マーカーも高度上昇していた。 血清カルシトニン, PTH 値は正常であった（表 1 ）.

入院後経過：以上の結果より乳癌骨転移による高 Ca血症クリーセと䛦断し $3,000 \sim 3,500 \mathrm{ml} /$ day の大

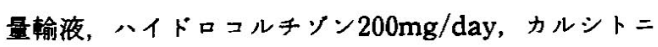
ン 80u/dayなどの投与を行なったところ著明な効果が みられ，約 1 週間治潦後，血清 $\mathrm{Ca}$ は $18.7 \mathrm{mg} / \mathrm{dl}$ より $8.0 \mathrm{mg} / \mathrm{dl}$ と正常値へ戻った。なお血清 $\mathrm{P}$ は正常值で
表 1 入院時検査值

\begin{tabular}{|c|c|c|c|}
\hline WBC & $8600 / \mathrm{mm}^{3}$ & GOT & 86 K.U. \\
\hline ABC & 468 万 $/ \mathrm{mm}^{3}$ & GPT & 28 K.U. \\
\hline Hb & $14.3 \mathrm{~g} / \mathrm{dl}$ & LDH & 1265 IU/I \\
\hline Ht & $44.6 \%$ & Cho.E & $2.3 \mathrm{IU} / \mathrm{I}$ \\
\hline \multirow[t]{2}{*}{ Plt } & $56.6 万 / \mathrm{mm}^{3}$ & rGTP & $66 \mathrm{IU} / \mathrm{ml}$ \\
\hline & & LAP & 114 IU/I \\
\hline $\mathrm{Na}$ & $141 \mathrm{mEq} / \mathrm{I}$ & ALP & $644 \mathrm{IU} / \mathrm{I}$ \\
\hline K & $4.9 \mathrm{mEq} / \mathrm{I}$ & T.cho & $273 \mathrm{mg} / \mathrm{dl}$ \\
\hline Cl & $97 \mathrm{mEq} / \mathrm{l}$ & Giu & 119 mg/dl \\
\hline $\mathrm{Ca}$ & $18.7 \mathrm{mg} / \mathrm{dl}$ & & \\
\hline $\mathbf{P}$ & $2.0 \mathrm{mg} / \mathrm{dl}$ & CEA & $20 \mathrm{ng} / \mathrm{ml}(Z$-GEL) \\
\hline BUN & $19 \mathrm{mg} / \mathrm{dl}$ & IAP & $795 \mu \mathrm{g} / \mathrm{ml}$ \\
\hline CRN & $1.3 \mathrm{mg} / \mathrm{dl}$ & & \\
\hline T.P & $7.2 \mathrm{~g} / \mathrm{dl}$ & カルシトニン & $88 \mathrm{pg} / \mathrm{ml}$ \\
\hline T.Bil & $0.52 \mathrm{mg} / \mathrm{dl}$ & PTH & $0.2 \mathrm{ng} / \mathrm{ml}$ \\
\hline
\end{tabular}

表 2 血清 Ca, P 值の推移及U゙治痖

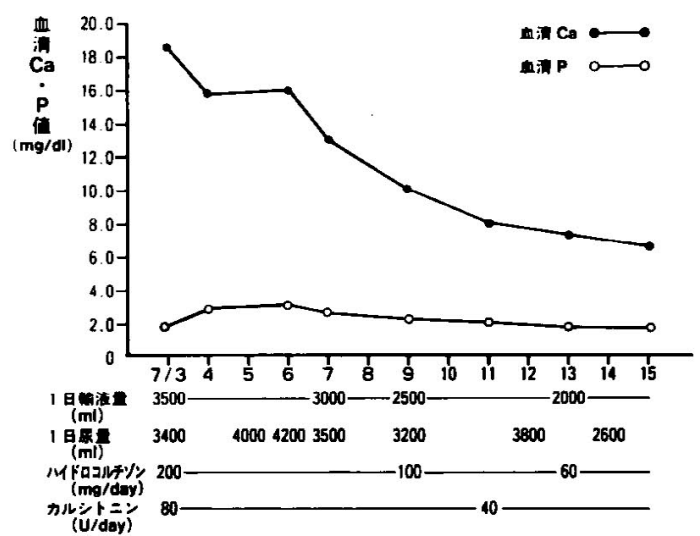

変化しなかった. BUN は30mg/dlより $10 \mathrm{mg} / \mathrm{dl}$ へ, ク レアチニンも $2 . \mathrm{lmg} / \mathrm{dl} よ り 0.8 \mathrm{mg} / \mathrm{dl} へ$ の改善がみ られた（表 2). 臨床的には意識障害も回復し, 呕気, 呕吐などの症状す軽快した。その後は順調に軽快し八 イドロコルチソンはは漸减し $50 \mathrm{mg} /$ day の内服とし, カ ルントニンは80u を隔日投与として退院した。

\section{考 察}

悪性腫瘍による高 $\mathrm{Ca}$ 血症の頻度は木村ら”の報告 では，悪性遁湯患者13,550例中481例 (3.5\%) といわ れている，一方乳癌に括ける高 Ca 血症の合併する頻 度は，岡田ら゙にによれば乳癌277例中高 $\mathrm{Ca}$ 血症をきた 


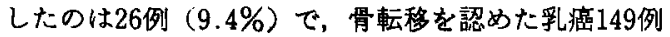
中26例 $(17.4 \%)$ に認められたという.

当院における Stage IV 及び再発乳癌の高 Ca 血症

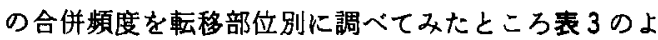
らになった。骨と他部位への転移では17例中 3 例 (17.6\%) と最り多く，骨転移のみでは 9 例中 1 例 (11.1\%)，他部位のみでは36例中 3 例 $(8.3 \%)$ で，全 体では62例中 7 例（11.3\%）であった，また，骨転移

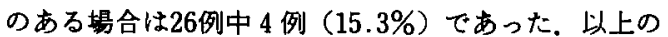
ことより，乳癌における高 Ca 血症の原因は骨転移の みならず，他部位転移の合併が重要である可能珄があ ることが示唆された。

一般的にいわれている悪性厙掦に打ける高 Ca 血症 の発生原因を表 4 に表した．骨転移によるるのでは， 畽瘍の増殖により骨が破垻されて起こるといら考え方 と，骨転移部の腫痬より osteoclast を増殖促進させる 物質が産生され osteoclastによる骨吸収により起こ るといら考え方がある゙，また畽㻛が産生する因子に よるものでは, OAF (Osteoclast Activating Factor) は分子量 2 万前後のペプチドで，IL-1はその内の一つ と考えられている5．PTH 様物質はPTH の生理活性 部分と頩似するポリベブチドで PTH 様作用がある. $1,25(\mathrm{OH})_{2} \mathrm{D}$ は ATL, maligmant lymphoma などで 高値を示するのが報告されている osteolytic sterol で ある. TGF (Transforming Growth Factor) は $\mathrm{TGF} \alpha, \mathrm{TGF} \beta$ などがあり骨吸収を促進することが知 られている.ブロスタダランディンす骨吸収作用があ るといわれている、乳癌の内分泌療法中の副作用とし

表3転移別からみた高カルシウム血症の頪度 (Stage IV及び再発勫成)

\begin{tabular}{|c|c|c|c|}
\hline 転移部位 & 症例数 & $\begin{array}{l}\text { 高カルシウ台 } \\
\text { 血 }\end{array}$ & 頻度 $(\%)$ \\
\hline i) 骨転移のみ & 9 & 1 & 11.1 \\
\hline ii）骨転移＋他部位転移 & 17 & 3 & 17.6 \\
\hline iii）他部位転移 & 36 & 3 & 8.3 \\
\hline 計 & 62 & 7 & 11.3 \\
\hline
\end{tabular}

表 4 要性框重における高カルシワム血症の原因
1) 骨転移
2）腫鹪による骨吸収促進物算の産生
3) ホルモン旗法
4) 原発性副甲状腺機能元進应の合併

(文献 ‘゙り引用)
て高 Ca 血症は 5 - 15\%に認められるといわれる677. タモキシフェンの投与を受けた $2.3 \%$ に高 $\mathrm{Ca}$ 血症を 認めたといら報告むある゙!。れらのことは乳癌の内 分泌療法の際，高 $\mathrm{Ca}$ 血症にも留意して㟝療すること を示唆していると思われる。

高 Ca 血症の症状は表 5 に示すように消化器症状, 中权神経症状, 肾症状, 循環器症状などがみられる，

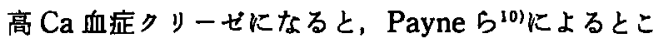
れらの症状が急激に変化し，血清 $\mathrm{Ca} は 15 \mathrm{mg} / \mathrm{dl}$ 以上 になりさらに BUN す上昇し乏尿になるとい5。これ らの症状は癌の末期症状と類似しているため，見逃さ れやすいため悪性腫瘍患者の治療の際には，血清 $\mathrm{Ca}$ 值の測定は重要之考える。

高 Ca 血症の治療法を表 5 に示した，生理食塩水の よらに Naを多く含んだ大量補液は，尿中の Ca 排泄 量を増加させる，フロセミドは Ca の再吸収を抑える. カルシトニンは骨の再吸収を抑奌る。グリココルチコ イドは抗腫灌効果, ブロスタグランディンの産生抑制, OAFの分泌抑制などが考えられている、インドメタシ ソはブロスタタランディンの合成を阻害する．今回の 症例では使用されなかったが，最近ミスラマイシンは 嶴丸腫瘍の治療薬として使用されていたが，副作用に

\section{表 5 高カルシウム血症の臨床症状と治療 (柾状) \\ 1) 消化器症状

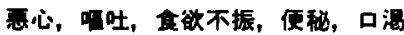 \\ 2) 中枢神経症状 易疲労感，脱力感，頭症，㑔眠，錯乱， 盾清 \\ 3) 胃症状

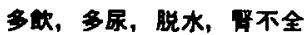 \\ 4) 循理器症状

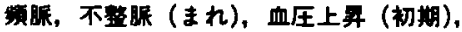 血圧低下（末期），QTc 短縮 \\ (治证)}

1）原疾息に对する治葹

2）高カルシウム血症に対する治璂

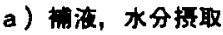

b) 莱袣
i）フロセミド
ii) カルシトニン
iii) インドメサシン
iv) グルココルチコイド
v) ミスラマイシン

（文献（9）より引用） 
血清 $\mathrm{Ca}$ を低下させる作用があり高 $\mathrm{Ca}$ 血症の治療楽 としてる使われてる.

\section{結 瞟}

1. 釈癌骨転移例における高 $\mathrm{Ca}$ 血症クリーゼの 1 治検例を報告した。

2. Stage IV 及び再発乳癌の高 $\mathrm{Ca}$ 血症は䯚と他部 位への轱移，骨転移，他部位転移の順で起こりやすく， 骨転移が誘因になっていると考えられる。

3. 乳癌の内分泌療法中, 副作用としての高 $\mathrm{Ca}$ 血症 にも注意する必要がある。

4. 悪性腫瘍の高 $\mathrm{Ca}$ 血症はその症状が癌の末期症 状と類似しているため見落とされやすく，また治療成 䒈る不良のため注意が必要である。

なお，本諭文の一部は第50回日本臨休外科医学会総会 （1988年11月，東京）にて発表した。

$$
\text { 文献 }
$$

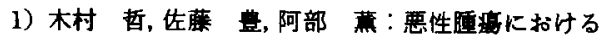
高カルシウム血症, 診断と治療 $74: 1018-1022$, 1986

2）岡田泰代，小川一諴，堸越 早他：乳满における高 カルシウム血症, 癌と化学璂法 $11: 1468-1474$, 1984

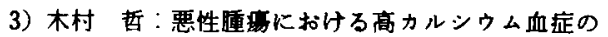

治癔法, 粕癌の臨 $3: 55$-63, 1988

4) Galasko CSB : Mechanism of bone destruction in the development of skeltal metastases. Nature 263: 507-508, 1976

5) Dewhirst FE, Stashenko PP, Mole JE, et al: Puritification and parcial sequence of human osteoclast-activating factor: Identity with interleuk in $1 \beta . \mathrm{J}$ Immunology $135: 2562-2568$, 1985

6) Davis HC, Wiseley AN, Ramirez G, et al : Hypercalcemia complicating breast cancer. Oncology 28: 126-137, 1973

7) Jessiman AG, Emerson $K$, Shalh $R C$, et al : Hypercalcemia in carcinoma of the breast. Ann Surg $157: 377-393,1963$

8) Legha SS, Powell K, Buzdar AU, Blumenschein GR: Tamoxifen-induced hypercalcemia in breast cancer. Cancer $47: 2803-2806,1981$

9）木村 哲, 大西 愛, 佐藤他：高 Ca 血症の治 療のガイドラインと実際・悪性瘇㷞による高 $\mathrm{Ca}$ 血症の治療法. Medical Practice 4: 1304-1308, 1987

10) Payne RL, Fitchett CW : Hyperparathyroid crisis, Survey of the literature and report of two additional cases. Ann Surg 161: 737-744, 1965

\section{HYPERCALCEMIA CRISIS IN BREAST CANCER WITH METASTASES TO THE BONES -A CASE REPORT-}

Hiroshi ANDO, Kenichi SUMIYOSHI, Jiro ANDO and Akio KOSAKA

Department of Surgery, Shimizu City General Hospital

We seldom encounter malignant tumors associated with hypercalcemia which leads to a crisis, and this paper describes a rare case of progressive beast cancer with bone metastases presenting with hypercalcemia crisis.

A 32-year-old woman with breast cancer having metastases to the bones, liver, lung and stomach complained of some symptoms such as nausea, vomiting, and drowsy 3 months after surgery. Minute examination revealed that she suffered from hypercalcemia crisis. Drip infusion and administration of hydrocortisone or calcitonin could provide drastic effects for her, and after one week a normalized serum calcium level and symptomatic remission were observed.

In addition, a review of breast cancers in stage IV or recurred ones presenting with hypercalcemia in our hospital revealed that hypercalcemia was most liable to occur in the cancers having metastases to the bones as well as other organs followed by those to the bones, then to the other organs, suggesting a possible contribution of bone metastases to hypercalcemia. We should take precaution ourselves against hypercalcemia in that it is often overlooked becaue of the similarlity in symptoms between hypercalcemia and terminal stage of malignant tumors, and it possibly occurs as an adverse reaction in endocrinologic therapy for breast cancer. 